\title{
TABAKO KAITINIMO SISTEMOS VERTINIMAS
}

\author{
Jonas Kairys \\ Vilniaus universiteto Medicinos fakulteto Sveikatos mokslu institutas
}

Raktažodžiai: tabako žalos mažinimas, tabako kaitinimo sistema, bedūmis tabakas.

\begin{abstract}
Santrauka
Tyrimo tikslas - įvertinti bedūmio tabako vartojimą, atsižvelgiant į mokslininkų parengtas ir paskelbtas mokslines publikacijas. Tyrimo metodai - įvairių šalių mokslinių tyrimų publikacijų analizè. Nagrinètos 23 mokslinès publikacijos, šaltiniai. Visa tai sisteminta ir ịvertinta.

Išvados. Nikotino vartotojams pasiūlius tabako produktų, galinčių sumažinti jų širdies ir kraujagyslių, plaučių ir onkologinių ligų riziką, ateityje galima sulaukti didelès naudos. Tabako kaitinimo sistemų produktų vartojimas sumažina tabako dūmuose esančių kenksmingų ir galimai kenksmingų medžiagų poveikị rūkantiems žmonèms.
\end{abstract}

\section{İvadas}

Akivaizdu, kad dauguma rūkančiųjų cigaretes puikiai išmano apie rūkymo žalą, o kai kurie bando mesti rūkyti, tačiau ilgam atsikratyti rūkymo pavyksta tik maždaug 5-10 proc. rūkančiujų̧. Pakaitine nikotino terapija ir antidepresantų vartojimas metimo rūkyti tikimybę sumažina tik nežymiai. Kai rūkymo visiškai atsisakyti neįmanoma, vienas iš galimų sprendimo būdų - kurti produktus, kurių kenksmingas poveikis sveikatai būtų mažesnis. Rūkymas yra viena iš pripažintų ir plačiai ištirtų širdies ir kraujagyslių ligų rizikos veiksnių ir mirties priežasčių. Cigarečių rūkymas Europos kardiologų draugijos gairèse nurodomas kaip ,,mirtina priklausomybe““ [1]. Beveik 50 metų trukusių tyrimų stebejjimas parodè, kad rūkaliai mire vidutiniškai 10 metų anksčiau, nei nerūkantieji [2]. Rūkalių mirties rizika dèl širdies ir kraujagyslių sistemos ligų per 10 metų yra maždaug 2 kartus didesnè, nei nerūkančių gyventojų [3].

Su tabako rūkymu susiję mechanizmai, dèl kurių atsiranda širdies ir kraujagyslių ligos - trombozè, endotelio disfunkcija ir uždegimas. Didžioji dalis šių padarinių gana greitai išnyksta metus rūkyti, tačiau nemažai jų išlieka il- gus metus, smarkiai padidindami daugelio skirtingų žmonių širdies ir kraujagyslių ligų tikimybę. Trys cigarečių dūmų komponentai laikomi potencialiais veiksniais, kurie prisideda prie širdies ir kraujagyslių ligos vystymosi. Tai nikotinas, anglies oksidas ir oksiduojančios dujos. Taip pat buvo atlikti tyrimai su policikliniais aromatiniais angliavandeniliais, dervomis ir kitais tabako dūmų komponentais, galinčiais prisidèti prie aterogenezès vystymosi [4].

Tyrimo tikslas - įvertinti bedūmio tabako vartojimą, atsižvelgiant ị mokslininkų parengtas ir paskelbtas mokslines publikacijas.

\section{Tyrimo objektas ir metodai}

Tyrimo objektas - bedūmio tabako vartojimo vertinimas. Tyrimo metodai - įvairių šalių mokslinių tyrimų publikacijų analizè, lyginamoji analize, įvertinimas.

\section{Rezultatai ir jų aptarimas}

Nikotinas greitai absorbuojamas iš tabako dūmų, todèl, surūkius vieną cigaretę, jo koncentracija arteriniame kraujyje būna $40-100 \mathrm{ng} / \mathrm{ml}$ [5]. Vidutinis nikotino suvartojimo kiekis cigareteje paprastai siekia 1-2 mg. Nors nikotino koncentracija kraujo plazmoje laikinai smarkiai padideja po kiekvienos surūkytos cigaretės, reguliariai rūkant, koncentracijos linkusios išlikti ir ilsintis. Šis kaupimosi modelis atitinka nikotino pusinès eliminacijos periodą, kuris yra 2 valandos [5]. Nemaža nikotino koncentracija plazmoje išlieka net po nakties pertraukos. Nuolatiniams rūkaliams gresia didelis nikotino poveikis 24 valandas per parą, kurio pasekme - poveikis endotelio disfunkcijai, lipidų sutrikimui ir atsparumui insulinui. Anglies oksidas yra pagrindinis cigarečių dūmų komponentas. Nuolatinių rūkalių karboksihemoglobino koncentracija yra vidutiniškai apie 5 proc., bet gali būti net 10 proc. ar daugiau tiems, kurie reguliariai rūko daug cigarečių. Tai priešingai nei nerūkančiųjų, kurių karboksihemoglobino koncentracija 0,5-2 procentai. Anglies oksidas greitai prisijungia prie hemoglobino, sumažindamas turimą hemoglobino kiekị, perneša deguonị ir slopina jo išsiskyrimą. İkvepimas tokios koncentracijos anglies oksido, kokia randama cigare- 
čių rūkalių organizme, sumažina pacientų, sergančių krūtinès angina, protarpiniu šlubavimu ir lètine obstrukcine plaučiu liga, toleranciją mankštai $[6,7]$.

Cigarečių dūmuose yra didelè oksidatorių koncentracija [8]. Šios medžiagos apima azoto oksidus ir ịvairius laisvuosius radikalus, esančius cigarečių dūmuose tiek dujų, tiek deguto fazèse. Oksidatoriai dūmuose sunaikina endogeninius antioksidantus, todèl rūkančiųjų kraujyje, palyginti su nerūkančiųjų, galima mažesnè C vitamino koncentracija kraujyje [9]. Cigarečių rūkymas didina lipidų peroksidacijos produktus plazmoje ir šlapime [10]. Manoma, kad oksidacinis stresas prisideda prie širdies ir kraujagyslių ligų progresavimo, įskaitant uždegimą, endotelio disfunkciją, lipidų susidarymo sutrikimus (mažo tankio lipoproteinų oksidacija) ir trombocitų aktyvaciją kraujyje [11].

Vienas naujausių modifikuotos rizikos tabako produktų, pasiūlytų pasaulinei rinkai, yra tabako kaitinimo sistema (angl. tobacco heating system, toliau - THS). Palyginus su ịprastinemis cigaretėmis, ši sistema tabaką ne degina, o kaitina $300-350{ }^{\circ} \mathrm{C}$, todèl rūkant sumažeja pavojingų arba galimai pavojingų medžiagų išsiskyrimas ir ịkvėpimas.

Pateikti duomenys rodo, kad palyginti su Kentukio universiteto etalonine cigarete 3R4F, tiek ịprastine, tiek ir mentolinè tabako kaitinimo sistema (angl. tobacco heating system version 2.2, toliau - THS2.2) leidžia gerokai sumažinti kenksmingų ir potencialiai kenksmingų sudedamųjų dalių (angl. harmful and potentially harmful constituents, toliau - HPHC) susidarymą. Mažesnis HPHC kiekis abiejose THS2.2 sukelia mažesnị toksiškumą, ivvertintą in vitro, atliekant citotoksiškumo ir mutageniškumo tyrimus, bei in vivo dviem skirtingais atvejais (90 dienų inhaliaciniai tyrimai su žiurkėmis). Autoriai G. Lo Sasso ir kt., B. Phillips ir kt., B. Titz ir kt. [12-14] atliko tyrimus ir ịvertino THS2.2 poveikị ligos mechanizmams. Tyrimai parode, kad THS2.2 poveikis, palyginti su 3R4F veikimu, yra mažesnis HPHC poveikio prasme, o tai mažina su liga susijusių perturbacijų amplitudès mechanizmus, mažeja ligos pasekmių sunkumas in vivo. Nurodoma, kad 3R4F pakeitimo i THS2.2 poveikio tyrimas arteja prie nutraukimo.

Autoriai I. Gonzalez-Suarez ir kt., A.R. Iskander ir kt., F. Zanetti ir kt., C. Poussin ir kt., M. van der Toorn ir kt. pateikia savo mokslines publikacijas [15-19] apie atliktus penkis in vitro sistemų THS2.2 toksikologinius tyrimus su žmogaus pirminèmis ląstelèmis. Šie tyrimai buvo skirti palyginti 3R4F dūmų poveiki su THS2.2 aerozoliu svarbiausiuose toksiškumo ląstelèms taškuose [15], nagrinèti organotipini kvėpavimo takų ir burnos žando gleivinès epitelị $[16,17]$, mechanizmus, susijusius su kraujagyslių uždegimu [18] ir endotelio disfunkcija [19]. Šių tyrimų rezultatai parodè, kad THS2.2 aerozolis yra mažiau toksiškas, nei 3R4F dūmai, o THS2.2 gali būti naudojama kaip modifikuotos rizikos tabako gaminys. Tyrimai išryškino susiliejančias ịrodymu linijas: tyrimų rezultatai parodè, kad THS2.2 gali būti mažiau rizikingas produktas. Norint tai patvirtinti, turi būti atliekami ilgesnès trukmès klinikiniai tyrimai, skirti ịvertinti ligos rizikos žymenis, bei nustatyti poveikio biologinius žymeklius. Autoriai nurodo, kad tikslinga plačiau nagrinèti ir aprašyti, ar vartojant THS2.2 nevyksta degimas (t. y. kad gaminamas aerozolis nèra dūmai), tęsti tolesnius klinikinius, suvokimo ir elgesio tyrimus, modeliuoti poveiki populiacijai.

Nepaisant plataus masto sveikatos stiprinimo priemonių, informacinių kampanijų ir farmakoterapinių metodų tobulinimo, nikotino priklausomybè ir toliau išlieka neišspręsta socialinè problema. Taikant ịvairias intervencijas, tam tikras (vis tiek didelis) procentas gyventojų, kuriems didesnè ligų, priklausomų nuo tabako poveikio, rizika, yra rūkantieji. Jeigu šios tendencijos negalima sustabdyti priklausomybès nuo nikotino gydymo ir kitais esamais metodais, cigarečių rūkymo dūmų neigiamą poveikị sveikatai galètų sumažinti jų pakeitimas kaitinamojo tabako produktais. Kaip nurodyta ankščiau, šių produktų vartojimas sumažina smarkiai rūkančių žmonių kenksmingų ir galimai kenksmingų medžiagų, esančių tabako dūmuose, poveikị. Pacientų susidomèjimo šia tabako gaminių forma stebėjimai rodo, kad vartotojų skaičius dideja, o gydytojai turètų daugiau žinoti apie THS produktus ir jų gaminius bei poveiki sveikatai [20,21]. Vieno Lenkijoje atlikto tyrimo rezultatai parodè, kad 49,7 proc. rūkalių, vartojusių alkoholi, pavartoję kaitinamojo tabako produktus (angl. heat-not-burn, sutr. HNB), negrižzo prie cigarečių rūkymo. Elektroninių cigarečių atveju šis skaičius buvo tik 16,1 proc. (2018 m. tyrimo, kurị užsakè Lenkijos sveikatos apsaugos ministerijos Cheminių medžiagų tarnyba, duomenys) [22]. Šio tyrimo respondentų atsakymuose nurodoma, kad tabako kaitinimo sistemos yra tinkama veiksminga alternatyva tradicinèms cigaretėms, o ne elektroninèms su skysčiu. Atsižvelgiant ị mokslinius ịrodymus, galima teigti, kad THS produktai yra saugesnè alternatyva sunkiai bandantiems atsisakyti rūkymo pacientams, kai priklausomybės nuo nikotino gydymas baigèsi nesėkme. Tuo pačiu metu būtina tęsti tyrimus, kurių tikslas - įvertinti ilgalaikị šių produktų poveikį vartotojų sveikatai.

Tabako kaitinimo sistemų produktų vartojimas siejamas su gerokai mažesniu kenksmingų medžiagų poveikiu pačiam rūkančiajam, minimalia oro tarša, mažesniu kancerogeniniu poveikiu, ribota arba visiškai pašalinta genų transkripcija, kurią sukelia cigaretès. Gali būti, kad šios tendencijos darys pastebimą poveikị ilgalaikiams klinikiniams parametrams. Tyrimų rezultatai leidžia manyti, kad, tikètina, ilgalaikiai epidemiologiniai tyrimai parodys gerokai mažesnę sergamumo ir mirštamumo riziką, palyginus su cigarečių rūkymu. 


\section{Išvados}

Ateityje galimi įvairūs iššūkiai. Viena vertus, nikotino vartotojams pasiūlius tabako produktų, galinčių sumažinti jų širdies ir kraujagyslių, plaučių ir onkologinių ligų riziką, ateityje galima sulaukti didelès naudos. Tabako kaitinimo sistemų produktų vartojimas sumažina kenksmingų ir galimai kenksmingų medžiagų, esančių tabako dūmuose, poveikị rūkantiems žmonėms. Kita vertus, reikètų atsižvelgti i kenksmingą nikotino poveikị, taip pat ị galimą pavojų, kad nikotino produktus pradès vartoti daugiau žmonių, ypač jaunimas.

\section{Literatūra}

1. Piepoli MF, Hoes AW, Agewall S, et al. ESC scientific document group. 2016 European guidelines on cardiovascular disease prevention in clinical practice: the sixth joint task force of the European Society of cardiology and other societies on cardiovascular disease prevention in clinical practice (constituted by representatives of 10 societies and by invited experts). Developed with the special contribution of the European association for cardiovascular prevention \& rehabilitation (EACPR). Eur Heart J 2016;37(29):2315-2381.

https://doi.org/10.1093/eurheartj/ehw106

2. Doll R, Peto R, Boreham J, et al. Mortality in relation to smoking: 50 years' observations on male British doctors. BMJ 2004;328(7455):1519.

https://doi.org/10.1136/bmj.38142.554479.AE

3. Prescott E, Hippe M, Schnohr P, et al. Smoking and risk of myocardial infarction in women and men: longitudinal population study. BMJ 1998;316(7137):1043-1047.

https://doi.org/10.1136/bmj.316.7137.1043

4. Benowitz NL. Cigarette smoking and cardiovascular disease: pathophysiology and implications for treatment. Prog Cardiovasc Dis 2003;46(1):91-111.

https://doi.org/10.1016/S0033-0620(03)00087-2

5. Henningfield JE, Stapleton JM, Benowitz NL, et al. Higher levels of nicotine in arterial than in venous blood after cigarette smoking. Drug Alcohol Depend 1993;33(1):23-29.

https://doi.org/10.1016/0376-8716(93)90030-T

6. Allred EN, Bleecker ER, Chaitman BR, et al. Short-term effects of carbon monoxide exposure on the exercise performance of subjects with coronary artery disease. N Engl J Med 1989;321(21):1426-1432.

https://doi.org/10.1056/NEJM198911233212102

7. Calverley PM, Leggett RJ, Flenley DC. Carbon monoxide and exercise tolerance in chronic bronchitis and emphysema. $\mathrm{Br}$ Med J (Clin Res Ed) 1981;283(6296):878-880.

https://doi.org/10.1136/bmj.283.6296.878

8. Church DF, Pryor WA. Free-radical chemistry of cigarette smoke and its toxicological implications. Environ Health Perspect 1985;64:111-126. https://doi.org/10.1289/ehp.8564111
9. Lykkesfeldt J, Christen S, Wallock LM, et al. Ascorbate is depleted by smoking and repleted by moderate supplementation: a study in male smokers and nonsmokers with matched dietary antioxidant intakes. Am J Clin Nutr 2000;71(2):530-536.

https://doi.org/10.1093/ajen/71.2.530

10. Morrow JD, Frei B, Longmire AW, et al. Increase in circulating products of lipid peroxidation (F2-isoprostanes) in smokers. Smoking as a cause of oxidative damage. N Engl J Med 1995;332(18):1198-1203.

https://doi.org/10.1056/NEJM199505043321804

11. Burke A, Fitzgerald GA. Oxidative stress and smoking-induced vascular injury. Prog Cardiovasc Dis 2003;46(1):79-90.

https://doi.org/10.1016/S0033-0620(03)00076-8

12. Lo Sasso G, Titz B, Nury C, Boue S, Phillips B, Belcastro V, Schneider T, Dijon S, Baumer K, Peric D, Dulize R, Elamin A, Guedj E, Buettner A, Leroy P, Kleinhans S, Vuillaume G, Veljkovic E, Ivanov NV, Martin F, Vanscheeuwijck P, Peitsch MC, Hoeng J. Effects of cigarette smoke, cessation and switching to a candidate modified risk tobacco product on the liver in apoe(-/-) mice - a systems toxicology analysis. Inhal Toxicol 2016b;28,226e240.

https://doi.org/10.3109/08958378.2016.1150368

13. Phillips B, Veljkovic E, Boue S, Schlage WK, Vuillaume G, Martin F, Titz B, Leroy P, Buettner A, Elamin A, Oviedo A, Cabanski M, De Leon H, Guedj E, Schneider T, Talikka M, Ivanov NV, Vanscheeuwijck P, Peitsch MC, Hoeng J. An 8-month systems toxicology inhalation/cessation study in apoe-/- mice to investigate cardiovascular and respiratory exposure effects of a candidate modified risk tobacco product, THS 2.2, compared with conventional cigarettes. Toxicol Sci 2016;149, 411 e432. https://doi.org/10.1093/toxsci/kfv243

14. Titz B, Boue S, Phillips B, Talikka M, Vihervaara T, Schneider T, Nury C, Elamin A, Guedj E, Peck MJ, Schlage WK, Cabanski M, Leroy P, Vuillaume G, Martin F, Ivanov NV, Veljkovic E, Ekroos K, Laaksonen R, Vanscheeuwijck P, Peitsch MC, Hoeng J. Effects of cigarette smoke, cessation, and switching to two heat-not-burn tobacco products on lung lipid metabolism in C57BL/6 and apoe-/-mice-an integrative systems toxicology analysis. Toxicol Sci 2016;149,441e457. https://doi.org/10.1093/toxsci/kfv244

15. Gonzalez-Suarez I, Martin F, Marescotti D, Guedj E, Acali S, Johne S, Dulize R, Baumer K, Peric D, Goedertier D, Frentzel $\mathrm{S}$, Ivanov NV, Mathis C, Hoeng J, Peitsch MC. In vitro systems toxicology assessment of a candidate modified risk tobacco product shows reduced toxicity compared to that of a conventional cigarette. Chem Res Toxicol 2016;29,3e18. https://doi.org/10.1021/acs.chemrestox.5b00321

16. Iskandar AR, Mathis C, Martin F, Leroy P, Sewer A, Majeed S, Kühn D, Trivedi K, Grandolfo D, Cabanski M, Guedj E, Merg C, Frentzel S, Ivanov NV, Peitsch MC, Hoeng J. 3-D nasal cultures: systems toxicological assessment of a candidate modified risk tobacco product. Toxicology Letters 2016;259:S82-S83. https://doi.org/10.1016/j.toxlet.2016.07.202 
17. Zanetti F, Sewer A, Mathis C, Iskandar A, Kostadinova R, Schlage WK, Leroy P, Majeed S, Guedj E, Trivedi K, Elamin A, Merg C, Ivanov NV, Frentzel S, Peitsch MC, Hoeng J. Systems toxicology assessment of the biological impact of a candidate modified risk tobacco product on human organotypicoral epithelial cultures. Chem Res Toxicol 2016;29(8):1252-1269. https://doi.org/10.1021/acs.chemrestox.6b00174

18. Poussin C, Laurent A, Peitsch MC, Hoeng J, De Leon H. Systems toxicology-based assessment of the candidate modified risk tobacco product THS 2.2 for the adhesion of monocytic cells to human coronary arterial endothelial cells. Toxicology 2016;339,73e86.

https://doi.org/10.1016/j.tox.2015.11.007

19. van der Toorn M, Frentzel S, Goedertier D, Peitsch M, Hoeng J, De Leon H. A prototypic modified risk tobacco product exhibits reduced effects on chemotaxis and transendothelial migration of monocytes compared with a reference cigarette. Food Chem Toxicol 2015;b:80, 277e286. https://doi.org/10.1016/j.fct.2015.03.026

20. Caputi TL, Leas E, Dredze M, et al. They're heating up: internet searchquery trends reveal significant public interest in heatnot-burn tobacco products. PLoS One 2017;12(10):e0185735. https://doi.org/10.1371/journal.pone.0185735

21. Marynak KL, Wang TW, King BA, et al. Awareness and ever use of heat-not-burn tobacco products among U.S. adults 2017. Am J Prev Med 2018;55(4):551-554.

https://doi.org/10.1016/j.amepre.2018.04.031
22. https://www.chemikalia.gov.pl/monitorowanie_rynku_ epapierosow.html

\section{ASSESSMENT OF TOBACCO HEATING SYSTEM J. Kairys}

Keywords: tobacco harm reduction, tobacco heating system, heat-not-burn.

Summary

The aim of the study was to evaluate the use of smokeless tobacco in the light of scientific publications prepared and published by scientists. Research methods - analysis of research publications of various countries. 23 scientific publications and sources were analyzed. All this is systematized and evaluated.

Conclusions: The provision of tobacco products by nicotine users can reduce the risk of cardiovascular, pulmonary and oncological diseases and can be of great benefit in the future. The use of tobacco heating system products by smokers reduces the exposure to harmful and potentially harmful substances in tobacco smoke.

Correspondence to: j.kairys@sec.lt

Gauta 2020-05-10

\section{KVIEČIAME PRENUMERUOTI „SVEIKATOS MOKSLŲ“ ŽURNALĄ 2020 METAIS!}

Žurnalas „Sveikatos mokslai“ (Index Copernicus, EBSCO host (Academic Search Complete), Gale (Academic OneFile), ProQuest (Ulrich's, Summon), Australia (ERA) 2012 Journal List (ERA ID 34962) skirtas visų specialybių gydytojams, slaugytojams ir kitiems specialistams, spausdina mokslinius straipsnius lietuvių, anglų kalbomis. Reikalavimai straipsniams atitinka mokslo leidiniams keliamus reikalavimus. Žurnalas kioskuose neparduodamas. Žurnalą, kuris leidžiamas kartą per du mènesius, galima užsiprenumeruoti visuose Lietuvos pašto skyriuose, taip pat internetu: www.prenumeruok.lt

Prenumeratos kaina nesikeičia: visiems metams - 36 EUR, šešiems mẻnesiams - 18 EUR, keturiems mẻnesiams - 12 EUR, dviem mẻnesiams - 6 EUR. Prenumeratos kodas: 5348.

Žurnalo autoriams straipsnių spausdinimas mokamas.

Redakcija 